\title{
The Influence of Loan Portfolio Quality on Sound Banking in CEMAC: The Importance of Bank's Internal and External Environment
}

\author{
Kadandji André $^{1} \&$ Djekna Votsoma ${ }^{1}$ \\ ${ }^{1}$ Saint Jerome Catholic University of Douala, Cameroun \\ Correspondance: Kadandji André, Saint Jerome Catholic University of Douala, P. O. Box: 5949, Douala, \\ Cameroun. E-mail: kadandji@gmail.com
}

Received: April 26, 2018

Accepted: May 11, 2018

Online Published: June 15, 2018

doi:10.5539/ijef.v10n7p136

URL: https://doi.org/10.5539/ijef.v10n7p136

\begin{abstract}
In this article we analyze the relationship between the loan portfolio quality and the soundness of the banking system in the Central African Economic and Monetary Community. The data used concern a panel of 41 banks in 4 countries in the Community for the period 2000 to 2013. For the analysis of the influence of different indicators, we use a model in nested equations. This study shows that taking into account both individual and macroeconomic indicators makes it possible to neutralize the effects of the deterioration of the quality of the credit portfolio on bank soundness. These indicators together improve the contribution of intermediation activity to the strength of banks.
\end{abstract}

Keywords: loan portfolio, sound banking, Z-score, dynamic panel

\section{Introduction}

The banking system contributes to the growth of economic activity and well-being by allocating finance through the granting of credits to viable investment projects. According to the IMF International Monetary Fund (2006), for this contribution to be significant, a sound and robust banking system is needed. However, experience with the various crises shows that banking systems are subject to instability and shocks that can disrupt banking activity and impose enormous costs on the economy. This instability of banking systems leads to the price of consciousness of the importance of the systemic repercussions that can result from the bankruptcy of a bank. This is justified by the surveillance of banking institutions and the monitoring of risks on the system due to the collective behavior of the banks.

Albulescu (2009) believes that in practice, banking systems are characterized by two sources of vulnerability. The first source is associated with a low level of risk diversification in banks' balance sheets and off-balance sheets. This risk arises in terms of credit risk, operational risk, liquidity risk, etc. The second source of vulnerability concerns the whole banking system and is represented by systemic risk. For the first source of vulnerability, the assessment of the bank's strength must take into account information on the asset (quality of the loan portfolio) and on the liabilities (equity) of the bank. To this end, the quality and composition of the bank's assets deserve a great deal of attention in assessing the soundness of banks. In the Economic and Monetary Community of Central Africa (CEMAC) (Note 1), the deterioration in the quality of the loan portfolio increased by about $17.1 \%$ in 2010 and at the same time there were about $16,3 \%$ of undercapitalized banks. Moreover, the latest evaluations of the financial sectors of the CEMAC countries by the IMF and the World Bank show that efforts are needed to improve the financial sector in this area. For example, Gulde-Wolf and Ghura (2013) advocate to mitigate the risks that threaten the stability of the financial sector in this area, the strict application of prudential standards and the acceleration of the restructuring of non-viable financial institutions

Abdou (2002) suggests that identifying factors that improve the soundness of the bank is useful for monetary authorities in more ways than one. Indeed, one of the missions generally assigned to the monetary authorities is the conduct of monetary policy (Note 2), one of the aims of which is the assurance of sound financing of the economy. To achieve this objective, there is a need for strong and viable banks. A banking system accumulating overdue receivables can not effectively play this role. The reason is simple: one must start from the fact that when the banks hold outstanding debts, they have to fund them. However, when these receivables are provisioned, the profitability 
of banks is reduced, which leads to a reduction in the capacity of these banks to finance economic activities. This shows that bad credit has a crowding-out effect on project financing, which can lead to economic decline. This is why we ask ourselves the following question: how to improve the influence of the quality of the loan portfolio on bank's soundness in the CEMAC?

The objective of this article is to analyze the role of individual and macroeconomic indicators in the relationship between credit quality and bank's soundness in the CEMAC. This allows us to assess the impact of external and internal factors on the bank's strength. This study shifts the debate around the determinants of the quality of the loan portfolio to the importance of the moderating and / or enhancing factors of the quality effects of the loan portfolio. It shows that joint consideration of individual indicators and macroeconomic indicators can improve bank's soundness in CEMAC countries. In the rest of the article, we briefly recall the empirical studies carried out on the subject. In the next section, we present our methodology and the variables used. Then, we present and interpret the results of our estimates before concluding this work.

\section{Review of Empirical Studies on the Soundness of Banks}

The private nature of borrower information makes it difficult to analyze the quality of the bank's assets. Besides the difficulty of analyzing the quality of bank assets, there is a problem in the study of the soundness of banks. In the theory of financial intermediation, it is assumed that the bank has private information about the behavior of its borrowers (Pop, 2005). This information on the quality of its borrowers affects the quality of its loan portfolio. The particular problem of building a soundness of a bank model lies in the possibilities of estimating this phenomenon.

The assessment of soundness must not be limited to the institution's ability to cope with a shock as it emerges, but it is also necessary to identify the factors that can influence the bank's capacities and the coach in a future imbalance. This makes it difficult to concentrate the concept in a single indicator and to choose the variables that explain it. Moreover, it is difficult to estimate the evolution of factors that influence solidity. Johnston et al. (2000) in their study of the vulnerability of the financial system, distinguishes four services for assessing soundness. The economic approach focuses on the sources of vulnerability in the financial system. While the risk assessment approach quantifies the risks and exposures of individual financial institutions. In addition, the surveillance approach involves an adequate monitoring and regulatory framework. The final approach focuses on assessing the individual vulnerability of financial institutions and the system.

In our study, we are interested in the latter approach, which reflects the interdependence between performance and bank's soundness, asset quality tests, stress tests, early warning systems, etc. An in-depth study mainly examines the impact of credit quality on the strength of banks. Indeed, the quality of a bank's assets is low, that is, when the bank's assets generate losses, it can become insoluble (Godlewski, 2004). Indicators of the quality of banks' assets are financial loans to the loan portfolio. Sundararajan et al. (2002) by publishing their study on indicators of Financial Strength (ISF) respond to the need for instruments to assess the strengths and weaknesses of a bank.

The analysis of TFRs began with the construction of theoretical models that explain the emergence of crises (Albulescu, 2009). These indicators have become particularly important with the development of quantitative techniques for assessing financial soundness. They have been used in early warning systems and stress tests. Some authors, such as Demirguc-Kunt and Detragiache (1998), Goyeau and Tarazi (1992) and Powo (2000), show that these individual indicators of robustness may offer limited information on the shock-resistance capacity of the banking system. Studies on risk management by banks can be grouped into two categories. One category uses individual data and the other uses macroeconomic data.

Demirgüç-Kunt and Detragiache (1998), using macroeconomic data, concluded that both in developing and developed countries, the unfavorable macroeconomic environment (low GDP growth and / or high inflation rate) negatively affects the quality of the credit portfolio and the profitability of banks. Thus, the macroeconomic environment can precipitate the banking system in a situation of distress. Hardy and Pazarbasioglu (1998) come to the same conclusion using a Logit model on Asian banks. These authors note that in most cases the crisis was preceded by an excessive increase in credit distribution and a significant increase in real interest rates that they used as a proxy of financial liberalization. For Abdennour and Houhou (2008), the institutional, legal and regulatory environment influences risk taking by banks in emerging countries. To this end, they propose an early warning system of banking difficulties including financial variables such as CAMEL (Note 3) and institutional, legal and regulatory variables, as a tool for determining institutions in difficult financial situations in these countries. The results of the Angora and Tarazi (2011) study on WAEMU show that the fall in inflation and the contraction of economic activity are the main factors that have weakened the banking system and triggered the crisis of the years 1980 . 
On the other hand, Diamond and Dybvig (1983) study on the rush to the counters highlighted the dominant role of bank-specific factors, thus minimizing the effect of the macroeconomic environment. Goyeau and Tarazi (1992), on the other hand, looking at the difficulties of banks in Europe, underline the crucial role of the insufficient coverage of risks by the banks as factor of vulnerability of these institutions. For Africa, Powo (2000) uses a multivariate Logit model to assess the probabilities of bank survival and the advent of a banking crisis in the UEMOA zone. Using data from the banks 'balance sheets, he finds that the elements related to the composition of the banks' portfolio (such as commercial paper) and the small amount of term deposits were decisive in the bankruptcy of banks during the second half of the 1980s. However, in this study, it did not analyze the mechanisms by which an accumulation of bad debts can weaken the bank by affecting its profitability and solvency. Soupmo Badjio (2009), by seeking to propose a model for predicting banking difficulties in the CEMAC zone, uses financial variables. He finds that three variables are statistically significant for the construction of the model of forecasting banking difficulties in the CEMAC.

These are ratios: equity on total loans, total deposits on total assets and revenues on total assets. It did not take into account the macroeconomic and institutional variables in its study.

Several techniques are used for studies of bank'soundness. Early warning systems are used to quickly identify the problems of a banking system, using indicators that emit signals related to the vulnerability of banks (Abdennour \& Houhou, 2008). Indeed, these techniques can be used by the supervisory authorities to identify banks with high risk exposure. In this case, specific methods such as the development of ratings are used to classify banks according to their financial health. Sahajwala and Bergh (2000) recognize that second-generation alert systems work well on small- and medium-sized banks engaged in traditional banking. Since it is assumed that CEMAC (Note 4) banks are only active in traditional banking activities, it may be useful to have a second-generation system in this subregion. Even if the literature on crisis anticipation using early warning systems is developed, in practice the use of these systems is reduced (Albulescu, 2009).

The other way of assessing financial strength is by conducting a stress test to assess the impact of a shock on the bank and its ability to resist such a shock. This can be illustrated by the European banks' stress-testing conducted by the European Central Bank (ECB) in 2014. Stress tests can be carried out both at the individual bank level and at the global level of the banking system. The major international banks to assess the impact of external shocks on their portfolios use stress tests for the first time. The use of these techniques is encouraged by the Basel Committee. Indeed, the Basel II agreements stipulate that institutions that use advanced methods of credit risk management must carry out stress tests. In the implementation of stress tests, two main approaches are used: the bottom-up approach and the top-down approach. According to the first approach, banks are responsible for simulating the baseline scenarios and for measuring their impact on the different variables of interest (Note 5) (De Bandt \& Oung, 2004). The second approach, systemic stress tests, is to evaluate the financial strength of the system as a whole. They make it possible to assess the banks' vulnerability to the shocks of real activity (pronounced recession), to increases in money market rates. The stress-test macros offer a wider range of applications, taking into account the risk of contagion. According to Albulescu (2009), these tests at the aggregate level provide approximate results, which simplify the reality, due to the complexity of the financial system. A limitation of stress tests at the individual level is the underestimation of liquidity when institutions reduce their exposures simultaneously. Another limitation is the difficulty of aggregating the results of bank tests and the difficulty of interpreting and comparing these results, as institutions use different techniques (Anand et al., 2014). This leads us to consider other quantitative models for analyzing the robustness of banks.

Discriminant analysis can be used to distinguish the group of fragile banks from the group of solid banks from a set of explanatory variables of a given indicator. This requires an analysis of the group of variables maximizing the variance between the groups and minimizing the variance within the groups. Altman (1968) to estimate the financial health of the firm using a model in a discriminating function. This analysis, which has certain advantages, is not without criticism. Eisenbeis (1977) criticizes discriminant analysis. It raises several problems inherent in this type of analysis. A classical assumption of linear discriminant analysis assume that the covariance variance matrix is the same for each group. When not respected, this property may affect the significance of the test of the differences between the averages for each group. Eisenbeis (1977) points out that there may also be problems related to the failure to include part of the population.

Some studies (Goyeau \& Tarazi, 1992; Doucouré \& Sène, 2014; Kadandji, 2016) using financial variables determined a bankruptcy indicator constructed from the Z-score model. The Z-score indicator allows to approximate the risk of failure and to test the fragility of the banks. Thus, Goyeau and Tarazi (1992) evaluate bank fragility within Europe, using the Z-score as a proxy. They show that bank failures are positively related to a high exposure to portfolio risks and a decrease in the degree of hedging. To do so, they propose a decomposition of the 
Z-score into a hedging component of the portfolio risk and a risk-adjusted performance component. The Z-score model is a model for quantifying the risks that characterize banking activity. The Z-scores are inversely correlated with the probability of insolvency, which has made this technique simple to measure the strength of credit institutions (Albulescu, 2009). A limit to the use of this model is however to note: the size and the concentration of the sample in a single sector leave a doubt on the precision of the coefficients.

From the above, the models used for macroeconomic or microeconomic studies of financial strength are: early warning systems, stress tests and other analyzes. Given the advantages and limitations of these different models, the Z-score model is more appropriate for our study. Indeed, in addition to being a probabilistic model, this model is more precise for our study horizon. Thus, we present in the following of this work the method of elaboration of a model of solidity of the banks of the CEMAC.

\section{Method}

As the majority of banks' assets are credits, an increase in their bad debts may lead to a decline in the bank's profitability. The increase in potential credit losses when unanticipated can also create a liquidity problem. The various reports of CEMAC's financial stability assessments by the Bretton Woods institutions show that credit risk remains an important factor in the vulnerability of banks in the subregion. This risk can be explained by certain factors that characterize the banking activities in this zone.

\subsection{Presentation of the Model}

Several models have been developed to measure the fragility of banks and analyze the robustness of banks. Given the characteristics of the models presented in the review of the literature to assess the soundness of banks in a context like that of CEMAC, the Z-score model is better indicated. Indeed, the indicator Z-score seems more reliable to decide directly on the degree of soundness of a bank. Given the objective and the conceptual framework of our study, we adapt the CAMEL model used by some supervisory authorities and several authors (Abdennour \& Houhou, 2008; Goyeau \& Tarazi, 1992).

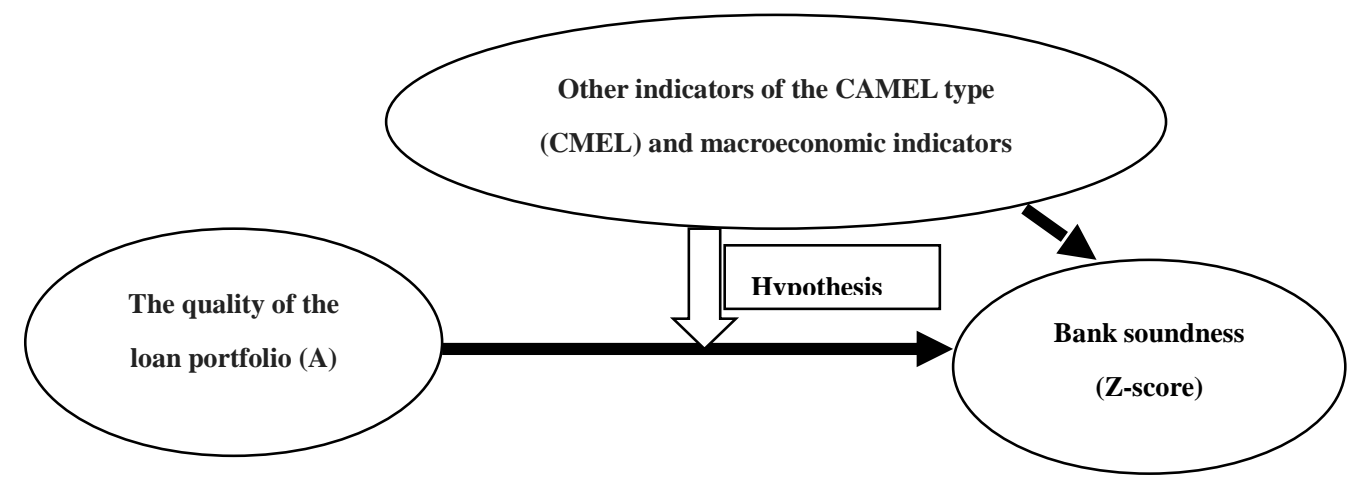

Figure 1. Conceptual frame

Source: author.

We apply the dynamic model approach to exploit the inter-individual and inter-temporal dimensions of the data. Our model is written as follows:

$$
Z_{i t}=\alpha Z_{i t-1}+\beta X_{i t}+\lambda M_{i t}+\eta_{i}+\varepsilon_{i t}
$$

with Zit the Z-score ratio, that is, the indicator of the bank's strength; Xit the vector of the set of CAMEL variables (variables related to capital, asset quality, liquidity and managerial variables); Mit the vector of macroeconomic variables (GDP growth rate and inflation rate); the fixed effect; the term of the error; $\alpha, \beta$ and $\lambda$ are the regression coefficients.

Dynamic models are characterized by the presence of one or more delayed endogenous variables among the explanatory variables as in the initial equation of our model. In this case, conventional estimation methods (OLS, LSDV and GLS) are inappropriate because they generate a biased estimate of the coefficients due to the correlation between the delayed endogenous variable and the individual heterogeneity of the regression residuals. To overcome these biases, especially when the duration is not long, several dynamic models are provided by the literature. To eliminate heterogeneity, some propose the method of instrumental variables. It is for this reason that the methods of generalized moments (GMM) become more efficient. They use all the delayed variables of the dependent variable and the exogenous explanatory variables as instruments. Arellano and bond (1991) 
estimated the dynamic models by the GMM in difference to bypass the problem of multiple collinearity and endogenousness. Thus, it is necessary to rewrite our model in first difference in order to eliminate the fixed effects. The model rewritten in difference is the following one:

$$
\Delta Z_{i t}=\alpha \Delta Z_{i t-1}+\Delta X_{i t} \beta+\Delta M_{t} \lambda+\Delta \varepsilon_{i t}
$$

Blundell and Bond (1998) have shown that the GMM system estimator is more efficient than the difference GMM estimator. Indeed, GMM in difference gives biased results in finite samples when the number of instruments is low. The difference GMM estimator suffers from two drawbacks: conceptual and statistical. The conceptual disadvantage is the differentiation that eliminates the specific effects. As for the statistical drawback, it deals with the weakness of instruments for regression in difference (Blundell \& Bond, 1998). This leads us to adopt the GMM as a system for estimating our model. In summary, the model which we wish to estimate is written in the form of the following system of equations:

$$
\left\{\begin{array}{l}
\Delta Z_{i t}=\alpha \Delta Z_{i t-1}+\Delta X_{i t} \beta+\Delta M_{i} \lambda+\Delta \varepsilon_{i t} \\
Z_{i t}=\alpha Z_{i t-1}+X_{i t} \beta+M_{i} \lambda+\eta_{i}+\varepsilon_{i t}
\end{array}\right.
$$

The variables used are a mixture of variables from the empirical literature and ratios that we consider to be relevant for the management of banks in the CEMAC. For the development of the model, we have panel data for 41 banks out of 50 CEMAC banks for the period 2000 to 2013.

\subsection{Presentation of the Variables Used}

The number and nature of these variables depends on our research objective and the availability of data.

\section{- $\quad$ The variable to be explained}

For this study, we propose a variable to measure the soundness of the bank from certain aggregates. Thus, in order to construct this variable, we choose two bank aggregates: equity and asset profitability, the components of which seem to explain the financial strength of the banks in the CEMAC. Indeed, several authors (Altman, 1968; Goyeau \& Tarazi, 1992) suggest using one of the proxies of bank soundness to evaluate financial soundness. Example of the Z-score which is often used as an indicator of the risk of fragility of the bank. Our analysis is based first of all on the construction of this variable and secondly on the determination of the factors influencing this variable. Recall that this indicator summarizes the information contained in the series of profitability, the volatility of this return and that relating to the coverage of risks by own funds (Solhi \& Mehdi 2012). Goyeau and Tarazi (1992) decomposed the Z-score into two parts. The first part considers both the level of return and the volatility of that return.

$$
Z=\frac{(\overline{R O A})+(F P / T A)}{\sigma R O A}=\frac{(\overline{R O A})}{\sigma R O A}+\frac{(F P / T A}{\sigma R O A}
$$

Where is the average return on the bank's assets, $E$ is the equity as a percentage of total assets (TA) and $\sigma$ ROA the ROA standard deviation as a proxy for yield volatility. To better capture the various effects of global risk on the portfolio, Solhi and Mehdi (2012) believe that the risk indicator of the asset represented by is more relevant than the $\sigma$ ROA. Indeed, $\sigma$ ROA takes into account not only the risks of individual assets by the standard deviations of asset returns, but also the interrelationships between these risks through the covariances of asset returns.

In our study, we adopt the Z-score inspired by Goyeau and Tarazi (1992); Doucouré and Sène (2014) and Kadandji et al. (2017). Indeed, the deterioration in asset quality has a direct impact on the bank's performance. Altman (1968) in his study on corporate bankruptcy defines an interval of the Z-score score to characterize companies. Thus, firms with Z-scores between 1.81 and 2.99 should be subjected to a more in-depth study since they are in the uncertainty zone. Companies rated Z-score greater than 2.99 are considered to have excellent financial health and those with a rating below 1.81 are in a critical financial health condition. While we are not in the same context, it seems appropriate to use this benchmark as a reference.

Table 1. Descriptive statistics of the Z-score of the CEMAC banks from 2000 to 2013

\begin{tabular}{cccccc}
\hline Variable & Obs & Mean & Std. Dev. & Min & Max \\
\hline zscore & 574 & 2.026026 & 1.72099 & -.6175089 & 10.5242 \\
\hline
\end{tabular}

Source: author based on data from the General Secretariat of COBAC.

Table 1 above shows that the average Z-score of the CEMAC banks is in the range of 1.81 to 2.99 defined by Altman (1968). With an average of around 2,026, the banks in the subregion are in the uncertainty zone. This demonstrates once again the importance of a thorough study of their financial health. To estimate the relationship between the Z-score and other factors, we define two types of exogenous variables. On the one hand we have 
variables that take into account the individual effects and on the other hand the variables representing the environment.

\section{- The explanatory variables}

We have identified the variables mainly used in the empirical literature on bank soundness. The individual variables selected are classified into groups.

The first group of variables measures the quality of the bank's assets. These variables can in turn be grouped in two. There is the ratio Net Loans / Total Assets (CRNTA) which represents the share of net credits granted by the bank in its assets. A positive sign of this indicator is expected. The other variables are: Receivables in Loan/Total Credits (CRESTCR); the Doubtful Receivables/Total Credits (CREDTCR) and the Doubtful Claims/Total Assets (CREDTA). An increase in these variables indicates deterioration in the quality of the bank's loan portfolio; the expected signs for these variables are negative. This first group consists of our variables of interest and the following groups consist of the control variables.

The variables in the second group measure the bank's exposure to liquidity risk. This is the first group of control variables. For this group, we have two ratios: Total Credit/Total Deposits (TCRDEP) and Total Deposits/Total Assets (DEPTA). The bank's excess liquidity can be assessed using indicators such as the refinancing of banks with the central bank, the banks' investments with the central bank, the hedging rate of the bank's sight liabilities by external assets (Wanda, 2007). We retain the above indicators because they compare the credit and deposit concepts that are highly valued for credit risk. Moreover, it is a concept that refers to the balance of transactions with customers. A positive sign is expected for these two variables.

The third group is that of the variables that refer to the management quality of the bank. We construct four ratios from the elements that the COBAC regulator considers important for the management of the bank. The Existing Provisions / Probable Claims (PROECRED) and Existing Provisions / Total Provisions (PROETCR) variables are expected to be positive. For the Provisions to Constitute / Claims Doubtful (PROCCRED) and Existing Provisions / Total Assets variables (PROETA), the expected sign is negative.

The fourth group of variables consists of variables representing the bank's ability to generate funds. For this group we consider two variables measuring the profitability of the bank. This is the return ratio defined by Net Income / Total Assets (ROA) and profitability ratio, ie Net Income / Equity (ROE). The expected signs of these variables are positive. Indeed, the bank's profitability increases its reserves and indirectly its capacity to cope with shocks.

The last group is that of the variables that rely on capital. The Shareholders' Equity / Total Assets (FPTA) is an indicator of financial effect. This is another measure of the capital adequacy of banks' credit portfolio. It was also the ratio Shareholders' equity / Total Loans (FPTCR). The latter represents, according to Godlewski (2004), a buffer to absorb the potential losses. As one of the main activities of the bank is the granting of credit, we expect these two variables to have a positive impact on the bank's soundness.

For the study of the financial health of the bank, one must take into account its environment. To do this, we retain certain macroeconomic variables that represent the environment for us. Given the lack of adequate data and the scarcity of analyzes on the CEMAC banking sector, we retain the GDP growth rate (GDP) and the consumer price index (CPI) as macroeconomic variables (Kadandji et al., 2017).

\subsection{The Quality of the Data and the Processing of Accounting Information}

Studies of vulnerability, fragility, stability and soundness of financial institutions use macroeconomic and financial data. These data may come from the bases used by specialized institutions such as the central bank, the regulatory body, the financial market, etc.

For this study, we use annual data, often used in the empirical literature. The statistical data used to conduct our analyzes are taken from the CERBER (Note 6) system used by the General Secretariat of the Central African Banking Commission (COBAC) and the annual reports of the central bank. This system allows the supervisory body, after the financial statements are transmitted by the banks, to restore their financial situation. This is the main piece-based control tool. The data collected for the period 2000 to 2013 relate to the annual balance sheets and annual profit and loss accounts of 41 banks located in Cameroon, Congo, Gabon and Chad. For calculating the ratios relating to the balance sheet and profit and loss account, we only work with the annual data retained by COBAC on 31 December of each year. The macroeconomic data used relate to the countries in which the banks in our sample are located.

Given the structure of our model and our data, we used the statistical and econometric software Stata / SE 12.0, to estimate our equations. The estimates produced results that should be presented. 


\section{Discussion of the Results of the Analysis}

The estimates of our different equations give us several results, which it is important to present in a summary table. Tables 2 and 3 below present the essential elements of the different regressions. We put the coefficients, the student's $t$ and the degree of significance.

We have performed several regressions step by step. Thus, the various estimates show several results. Indeed, we note in the first estimate that the influence of the variables related to the quality of the loan portfolio on the strength of banks is mixed. The link between the variables representing the quality of the loan portfolio and the Z-score is, on the whole, significant at the 5\% level, with the exception of the variable CRESTCR (the level of overdue receivables compared to total loans gross). The delayed variable has a positive and significant effect on the bank's strength (Z-score) at the $1 \%$ threshold, which proves that bank robustness is dynamic. Moreover, among the variables related to the quality of the credit portfolio, the net credit distribution rate (CRNTA) contributes significantly to the strength at the 5\% threshold (unit increase of this ratio results in an increase in the bank's strength of approximately 0.96 ). The bad debt ratio (CREDTCR) with a positive sign contradicts the theoretical prediction. This may be due to the quality of information provided by the banks to the supervisory body and even to the pricing of banking products in the area. The variable representing the importance of the deterioration in asset quality, that is to say the total portfolio of the bank's assets (CREDTA), significantly reduces bank soundness at the 5\% threshold (at this threshold, a degradation of the portfolio quality of the unit bank reduced the bank's strength by about 1.74), confirming the negative influence of the deterioration of the bank's portfolio on bank robustness. The contribution of the variable representing the distribution of net credits by the bank (CRNTA) to bank soundness confirms the theoretical prediction.

We can argue that the strength of a bank depends on its previous situation, its ability to distribute credit, and the quality of its credit portfolio and assets. This model shows that the increase in the level of credit granted may deepen banks' exposure to credit risk. This can be explained by the positive correlation between the credit distribution rate and bad debts and / or suffering. However, the increase in the credit distribution rate may lead to an increase in the level of non-performing loans. This result is in line with Rochet's (2008) assessment of certain crises. This author observes that certain crises following the example of the 1995-1999 Japanese crisis were preceded by a phase of dramatic expansion of bank credit.

When the liquidity risk variables (DEPTA and TCRDEP) are added, it can be seen that the variable CRNTA, that is, the capacity for the distribution of net credits by the bank, becomes insignificant. However, the CREDTCR and CREDTA variables related to the quality of the loan portfolio remain significant at the 5\% threshold with mixed influences. In addition, the variable related to the level of outstanding receivables (CRESTCR) becomes significant at the $10 \%$ threshold. Indeed, when the banker takes into account the level of liquidity in his structure, he may be lax in the process of granting credit, which may lead him to grant credits that will increase the level of his non-performing loans. All other things being equal, the influence of the deterioration in the quality of the credit portfolio represented by the variables CRESTCR, CREDTA and CREDTCR on the strength of the bank becomes important. Indeed, there is a slight increase in the coefficients of these variables. The level of liquidity coverage of the bank (DEPTA) positively influences the strength of the bank at the 10\% threshold (an increase in the liquidity of a unit results in a strength increase of about 0.79 at this threshold). At the same time, the bank's deposit processing function (TCRDEP) significantly contributes to the bank's strength at the $1 \%$ threshold (at this threshold, an increase in the intermediation capacity of one bank increases the strength of this bank by about 0.03). The importance of this variable in this model would mean that the banks' ability to transform deposits into loans is high. Thus, we can say that the bank's focus on managing its liquidity can make it solid.

By adding to our baseline equation some of the good governance indicators defined by the COBAC regulation, there is a significant change in the results. For this equation (estimate 3), the variable related to the level of distribution of net credits (CRNTA) is significant at the 5\% threshold. The other variables (CREDTCR and CREDTA) become less meaningful (their thresholds of significance decrease from 5\% to 10\%) by keeping their signs. This shows that when the quality of management is good, there is a good chance that the credit process will be meticulous. This attitude improves the bank's strength through increasing its ability to distribute good quality credits. Moreover, it is realized that the variable representing the degradation of the quality of the management (PROCCRED) significantly reduces the bank solidity to the threshold of $10 \%$. Given the effects of the variables characterizing the good governance of banks in the CEMAC, it can be said that these indicators are considered relevant for COBAC, they are less so for our model. Hence the importance for COBAC to define qualitative indicators of banking governance. However, the importance of taking these variables into account is important because the introduction of these variables into the model has reduced the significance of the negative influence of the deterioration in the quality of the asset portfolio on the bank soundness. This makes it possible 
to stabilize or increase bank soundness.

In addition to the variables related to the quality of the loan portfolio, the variables representing the level of capitalization of the bank (estimate 4) are added. The capitalization level indicators take into account own funds (FPTA and FPTCR). Since the bank's activity is essentially the granting of loans, these variables can be considered as the best indicators of banking difficulties (Berger, 2010; Gouriéroux \& Tiomo, 2007; Petey, 2004; Tartari, 2002). The introduction of these variables reveals some major facts. Indeed, the variable representing the quality of the portfolio of assets of the bank (CREDTA) which had a negative sign, becomes non-significant. While the other variables representing the quality of the loan portfolio with positive signs (CREDTCR and CRNTA) remain significant at the $5 \%$ threshold. The level of significance of the ability to distribute net credits by banks increases from $5 \%$ to $1 \%$, reflecting the growing importance of credit distribution in CEMAC (an increase of one the ability to distribute net credits leads to a 1.13 increase in bank soundness). The paradox lies in the influence of the bad debt rate on bank soundness (Kadandji, 2016). It is found that this variable positively influences solidity at the threshold of 5\%, which is contradictory to theoretical predictions. Although the asset quality variable that negatively influences the strength has become insignificant, the moderating effect of the capitalization level is qualified by the positive influence of the variable CREDTCR. In addition, the capital variables are not significant.

Let us introduce the variables related to the profitability of the bank (ROA and ROE) in the equation of departure (estimate 5). The estimate of this new equation shows that the net credit rate (CRNTA) significantly increases bank soundness at the 5\% threshold. ROE and ROA, ie the ratio of net profit to equity and the ratio of net income to total assets, enable the bank to measure its performance relative to its own funds and assets. Indeed, when the bank grants sound credits, its profitability increases, indirectly its reserves increases and its solidity increases. By increasing its reserves, the bank increases its financial capacity to cope with shocks. The moderating effect of these variables is quite noticeable, as all the variables related to the deterioration of the loan portfolio become insignificant.

For the rest of the estimates of the equations with the variables by group, we added the macroeconomic variables. The first observation that comes from this estimate is that the results remain almost the same for the variables related to the quality of the loan portfolio (CRNTA, CRESTCR, CREDTCR and CREDTA). As for macroeconomic variables, they are not significant in explaining the robustness of banks. It should be noted that the pro-cyclicality of banks does not have a moderating effect on the influence of the deterioration in the quality of the loan portfolio on the strength of banks. A pro-cyclical situation may rather amplify the effects of the deterioration of the credit portfolio on bank soundness. Indeed, with the inclusion of macroeconomic indicators, the threshold of significance of the influence of the variables representing the deterioration in the quality of the loan portfolio remained at $5 \%$.

The coefficients of the significant variables remained substantially equal to those of the basic equation. These remarks lead us to say that taking macroeconomic variables into account can lead to an increase in the distribution of credit, which can lead to an increase in the level of bad debts. It is for this reason that the negative influence of the deterioration in the quality of the asset portfolio does not fall. However, it should be noted that, despite the bank's main mission, which is the financing of the economy, the banking landscape of CEMAC is characterized by low credit activity (Soupmo Badjio, 2009; Kadandji, 2016). Some studies show that this weak lending activity may be due to factors such as: difficulty in disseminating information, inadequate institutional environment and inefficiency of the judicial system (Godlewski, 2005). It is therefore not surprising that the variables measuring the quality of the bank's loan portfolio are statistically significant for a bank soundness model in the CEMAC.

To estimate the collective effect of certain indicators, we have made estimates of the nested equations. These estimates show several interesting results, as the moderating or enhancing effect of jointly taking into account certain groups of variables is perceptible. In Table 7, it can be seen that taking jointly the variables related to liquidity and those linked to the quality of the bank's governance (estimate 7) makes it possible to counteract the adverse effects of the degradation of the quality of the credit portfolio on bank soundness. In this equation, all variables related to the quality of the loan portfolio become insignificant. However, the deposit processing function (TCRDEP) is significant at the $1 \%$ threshold and the level of deposits in the total assets (DEPTA) at the $5 \%$ threshold. However, the contribution of these two variables to bank soundness can be reduced significantly to the $1 \%$ threshold by a poor governance policy (PROCCRED).

When the variables related to the level of capitalization are added to the previous equation (estimate 8), the moderating effect of all these variables improves. All the variables related to the quality of the loan portfolio 
remain insignificant and the significance level of the variable representing bad governance increases from $1 \%$ to 5\%. Even as the deposit level also becomes insignificant, the deposit transformation function remains significant at the $1 \%$ threshold. By adding the variables representing the profitability of the bank, we have an almost complete model with all the variables related to the bank (estimate 9). The estimation of this equation shows that all variables with a negative sign before become non-significant. Only the variable related to the transformation of deposits in credits (TCRDEP) is significant at the $1 \%$ threshold. Thus, the detrimental effect of the deterioration in the quality of the loan portfolio is reduced, thus maintaining or increasing bank soundness. This result is consolidated by taking macroeconomic variables into account (estimate 10).

In order to assess the moderator or enhancer effect in the interleaved equations, two main findings emerge. First, we see that the intermediation function represented by the transformation of deposits into loans (TCRDEP) remained significant at the $1 \%$ threshold. This demonstrates the importance of indirect finance in CEMAC. This result demonstrates that over-liquidity is harmful to the strength of banks. Second, when all internal variables and macroeconomic variables are taken into account, only the transformation of deposits into loans remains significant at the $1 \%$ threshold in the model. Consideration of these variables will have helped to neutralize the detrimental effect of the deterioration in credit quality on the strength of the credit portfolio (the difference between the significant variables between estimate 1 and estimate 10). To this end, bankers are not to suffer the effects of the deterioration in the quality of their credit portfolios, must put in place policies taking into account all internal aspects of the bank and the macroeconomic environment.

For the validity of our estimates, we conducted several tests. From the various estimates, the delayed variable of the dependent variable is significant, confirming the dynamic quality of our model. In addition, for all these estimates, Arellano and Bond AR (2) tests reject the second order autocorrelation hypothesis at the 5\% threshold, confirming the absence of an AR(2). In addition, Sargan's or Hansen's over-identification tests validate the choice of instruments for all our equations. The model as a whole is significant at the $1 \%$ threshold, according to Fisher's test results. For the robustness of these results, we used the Least Squares Dummy Variable Corrected (LSDVC) method. The results obtained by this method are relatively close to those obtained by the method of Blundell and Bond (1998).

\section{Conclusion}

In order to analyze the relationship between the credit portfolio quality and bank soundness, we opted for a dynamic Z-score model. Indeed, the indicator Z-score seems to contain all the information on the financial health of the bank. The risk-adjusted performance and the hedging of credit portfolio risk by the bank's own funds are contained in this indicator (Goyeau \& Tarazi, 1992). Next, we defined five variables of the individual variables as explanatory variables: variables related to the quality of the loan portfolio; liquidity risk variables; the variables related to the quality of management; the variables related to the level of capitalization and the variables related to the profitability. Given the macroeconomic environment in which the bank operates, we added two macro variables to the individual variables. In order to assess the effects of the groups of control variables on the relationship between credit quality and bank soundness, we have made several estimates. For these estimates, using the dynamic model and data type, we used the GMM system of Blundell and Bond (1998).

Overall, we find that the different models are significant. Several findings emerge from these different models. When the Z-score is estimated by variables related to the quality of the loan portfolio, the ambiguous influence of the deterioration in the quality of the loan portfolio is significant at the $5 \%$ threshold. Given the signs of the different variables related to the quality of the loan portfolio, the debate remains mixed. This result confirms the theoretical debate on the influence of the deterioration in the quality of the loan portfolio on the financial health of the bank. The variables related to the quality of management are not significant on the whole, but their presence in the model plays an important moderating role. The degree of significance of the influence of the deterioration in the quality of the credit portfolio on the soundness of banks is reduced in the presence of variables related to the quality of management. As for the level of capitalization, the moderating effect of the presence of these variables remains ambiguous. However, the presence of these variables improves the significance of the variable related to the distribution of credits and indirectly the bank soundness. Taking into account the macroeconomic variables, the influence of the deterioration in the quality of the loan portfolio on the strength of banks is not improving. This result confirms the idea defended by Angora and Tarazi (2011) who think that macroeconomic factors are likely to influence the situation of banks. This is in line with the conclusion of Demirguc-Kunt and Detragiache (1998) who find that in both developing and industrialized countries the macroeconomic environment influences the quality of the portfolio and the profitability of banks.

In order to evaluate the moderator or amplifier effect of the variables grouped in the nested equations, we obtain 
two observations. First, concerning the intermediation function, it appears that the latter is important in the CEMAC. It makes a significant contribution to improving banks' ability to cope with shocks. The importance of the function of transforming deposits into credits leads us to conclude that banks' excess liquidity is not good for their soundness. Then, when all control variables (CAMEL variables and macroeconomic variables) are taken into account, only the function of transforming deposits into credits remains significant in the model. The injection of these variables into the model will have eliminated the ambiguity about the influence of the deterioration in the quality of the loan portfolio on bank soundness.

The results concerning the moderating effects of the negative influence of the deterioration in the quality of the loan portfolio on bank soundness by the other variables seem satisfactory. The major contribution of our study is to show that some individual and macroeconomic factors may influence the effects of the quality of the credit portfolio on the strength of banks. To reduce the adverse effects of the deterioration in the quality of the loan portfolio, banks and banking authorities must put in place policies that take into account all internal aspects of the bank and the macroeconomic environment. This proposal should lead regulators and bank managers to deepen their reflection on the financial soundness indicators of banks in the CEMAC. The quality of this model can be improved by integrating cultural and institutional variables. This is only possible if the barrier to full data access on the CEMAC banks is lifted. It is for this reason that Soupmo Badjio (2009) points out the danger posed by the lack of financial communication in CEMAC, for the development of research and the banking sector in this subregion. In addition, the IMF and the World Bank evaluate the financial sectors of the CEMAC countries to find that there are reforms to improve the financial sector in this area. Our study is similar to that of Gulde-Wolf and Ghura (2013), who advocate to mitigate the risks that threaten the stability of the CEMAC financial sector, strengthening the regional regulatory authority, strict enforcement of prudential standards and the consideration of macroeconomic indicators in the determination of rules.

\section{References}

Abdennour, F., \& Houhou, S. (2008). Un modèle d'alerte précoce de difficultés bancaires pour les pays émergents. Economie Internationale, (114), 69-92.

Abdou, R. (2002). Les déterminants de la dégradation du portefeuille des banques: Une approche économétrique et factorielle appliquée au système bancaire nigérien. Etudes et Recherches, BCEAO.

Albulescu, C. T. (2009). La stabilité du secteur financier en Roumanie dans la perspective de son adhésion à l'UEM, Thèse de Doctorat en Sciences Economiques, Université de Poitiers et Université de l'Ouest de Timisoara

Altman, E. I. (1968). Financial ratios, discriminant analysis, and the prediction of corporate Bankruptcy. Journal of Finance, 23(4), 589-609. https://doi.org/10.1111/j.1540-6261.1968.tb00843.x

Anand, K., Bédard-Pagé, G., \& Traclet, V. (2014). L'application des tests de résistance au système bancaire canadien: Une approche systémique. Banque du Canada, Revue du Système Financier, 69-78.

Angora, A. E. (2009). Système d'alerte avancée des crises bancaires: Une approche fondée sur les modèles multinomiaux. Thèse de Doctorat en Sciences Economique, Université de Limoges.

Angora, A., \& Tarazi, A. (2011). Crises bancaires dans les pays de l'UEMOA: Un système d'alerte avancée fondé sur une approche logit multinomiale. Brussels Economic Review, 54(1), 21-50.

Arellano, M., \& Bond, S. (1991). Some tests of specification for panel data: Monte Carlo evidence and an application to employment equations. Review of Economic Studies, 58, 277-297. https://doi.org/10.2307/2297968

BCE. (2014). Aggregate report on the comprehensive assessment (p. 178).

Berger, R. (2010). Les régulateurs ont apporté quelques assouplissements au calcul du ratio de liquidité, mais sans en bouleverser la logique. L'AGEFI, 17 décembre.

Bordes, C. (2005). Droit, Economie et Justice dans le secteur bancaire. Banque et risque systémique. Septième conférence Banque et risque systémique, Grand' Chambre de la Cour de cassation.

De Bandt, O., \& Oung, V. (2004). Bilan des stress tests menés sur le système bancaire français. Banque de France, Revue de la Stabilité Financière, (5), 55-72.

Demirgüç-Knut, A., \& Detragiache, E. (1998). The determinants of banking crises in developing and developed countries. IMF Staff Papers, 45(1), 81-109. https://doi.org/10.2307/3867330

Diamond, D. W., \& Dybvig, P. H. (1983). Bank Runs, Deposit Insurance, and Liquidity. The Journal of Political 
Economy, 91(3), 401-419. https://doi.org/10.1086/261155

Doucouré, F. B., \& Séné, B. (2014). Les déterminants macroéconomiques de l'indice de stress bancaire dans les pays de l'UEMOA.BCEAO, Revue Economique et Monétaire, (16), 9-28.

Eisenbeis, R. A. (1977). Pitfalls in the application of discriminant analysis in business, finance, and economics. Journal of Finance, 32(3), 875-900. https://doi.org/10.1111/j.1540-6261.1977.tb01995.x

FMI. (2006). Indicateurs de solidité financière: Guide d'établissement. Fonds Monétaire International, Washington D.C.

Gammadigbé, V. (2012). Stress test macroéconomique du système bancaire de l'UEMOA. Munich Personal RePEc Archive,

Godlewski, C. J. (2004). Le Rôle de l'environnement réglementaire, légal et institutionnel dans la défaillance des banques: Le cas des pays émergents. Banque \& marchés, (73), 20-31.

Godlewski, C. J. (2005). Information, organisation et prise de risque dans la banque. Thèse de Doctorat de Sciences de Gestion, Université Robert Schuman Strasbourg III.

Gourièroux, C., \& Tiomo, A. (2007). Risque de crédit : une approche avancée. Les cahiers du CREF, CREF 07-05.

Goyeau, D., \& Tarazi, A. (1992). Evaluation du risque de défaillance bancaire en Europe. Revue D'Economie Politique, (2).

Gulde-Wolf, A. M., \& Ghura, D. (2013). Communauté Economique et Monétaire de l'Afrique Centrale (CEMAC): Rapport des services du FMI sur les politiques communes des Etats membres. Rapport du FMI, $\mathrm{N}^{\circ} 13 / 322$.

Hardy, D. C., \& Pazarbasioglu. (1998). Leading indicators of banking crises: What Asia different? IMF Working paper, $\mathrm{N}^{\circ} \mathrm{WP} / 98 / 91$.

Johnston R. B., Chai, J., \& Schumacher, L. (2000). Assesing Financial System Vulnerabilities. IMF Working Paper, $\mathrm{N}^{\circ} 76$.

Kadandji, A. (2016). Qualité du portefeuille de crédits, capitalisation et solidité bancaire dans la Communauté Economique et Monétaire de l'Afrique Centrale (CEMAC). Thèse de Doctorat en cotutelle internationale entre l'Université Gaston Berger de Saint-Louis et l'Université de Douala.

Kadandji, A., Fall, M., \& Koum, E. F. (2017). Les exigences de capitalisation et la solidité bancaire dans la CEMAC: Le rôle de l'environnement interne et externe de la banque. $5^{\text {ème }}$ Congrès des Economistes Africains, organisé par le Département des Affaires Economiques de l'Union Africaine à Malabo.

Mojon, B. (1996). Ratio Minimum de capitalisation et cycle de crédit. Revue d'Economie Politique, 106(4), 727-743.

Petey, J. (2004). Les déterminants du risque d'insolvabilité dans l'industrie bancaire. Une approche en termes de frontière de production. Recherches Économiques de Louvain / Louvain Economic Review, 70(4), 401-424.

Pop, A. (2005). La politique de dette subordonnée comme alternative au III ${ }^{\mathrm{e}}$ pilier de Bâle II: Est-elle faisable? Recherches Économiques de Louvain / Louvain Economic Review, 71(2), 193-222.

Powo, F. B. (2000). Les déterminants des faillites bancaires dans les pays en voies de développement: Le cas de l'Union Économique et Monétaire Ouest Africaine (UEMOA). Cahier $N^{\circ}$ 2000/02, Université de Montréal, Département de sciences économiques.

Rochet, J. C. (2008). Comment reformer la réglementation prudentielle: Les leçons à tirer de la crise des subprimes. Revue d'économie financière, Numéro hors-série: Crise financière: analyses et propositions, 387-390.

Sahajwala, R., \& Bergh, P. V. D. (2000). Supervision risk assessment and early warning system. Basel committee on banking supervision Working paper, $\mathrm{N}^{\circ} 4$.

Solhi, S., \& Mehdi, A. (2012). Prévention du risque de défaillance des banques de la région MENA: Analyse par équations simultanées en données de panel. Economic Research Forum working paper, N $\mathrm{N}^{0} 693$.

Soupmo, B. D. (2009). Réglementation et modèle de prévision de difficultés bancaires en zone CEMAC. Cahier de recherche/working paper, $\mathrm{N}^{\circ}$ 200902/02, Ecole de Gestion de l'Université de Liège, p. 31.

Sundararajan, V., Enoch, C., José, A. S., Hilbers, P., Krueger, R., Moretti, M., \& Slack, G. (2002). Financial 
soundness indicators: Analytical aspects and country practices. International Monetary Fund, occasional paper, $\mathrm{N}^{\circ} 212$.

Tartari, D. (2002). De la régulation en matière des capitaux propres du système bancaire. Thèse de Doctorat en Sciences Economique et Sociales, Université de Fribourg.

Wanda, R. (2007). Risques, comportements bancaires et déterminants de la surliquidité. La Revue des Sciences de Gestion, (228), 93-102.

\section{Notes}

Note 1. CEMAC born from ashes of UDEAC, is made up of six countries: Cameroon, Congo, Gabon, Equatorial Guinea, Central African Republic and Chad

Note 2. Monetary policy affects the real sector through its various channels of transmission. These transmission channels can be grouped into three categories: the traditional interest rate channel, the exchange rate channel, and credit channels. The bank credit channel is based on the idea that banks play a specific role within the financial system, as they are particularly well placed to solve asymmetric information on credit markets.

Note 3. CAMEL (S) is an analytical framework that defines six (06) categories of variables to assess and hedge the financial and non-financial risks facing financial institutions. The six criteria are: capital adequacy; the quality of the assets and the portfolio (Asset quality); management and corporate governance (management quality); profitability (Earning ability); liquidity position and sensitivity to market risk.

Note 4. The banking sector of the CEMAC consists of local banks, subsidiaries of West African banks and certain subsidiaries of Western banks

Note 5. A bank can measure the impact of a shock on its profitability, its solvency or its level of risk.

Note 6. The acronym CERBER is used for Collection, Exploitation and Restitution to the Banks and Financial Establishments of the Regulatory States. From this system, COBAC uses its SYSCO rating for the assessment of banks in the area. Although the data from this device are not publishable, we have been able to obtain, thanks to the collaboration of some external and internal people at COBAC.

\section{Appendix}

Appendix 1. Summary of the results of the estimates with the variables taken by group

\begin{tabular}{|c|c|c|c|c|c|c|}
\hline & Zscore $(1)$ & Zscore(2) & Zscore(3) & Zscore(4) & Zscore (5) & Zscore (6) \\
\hline L.zscore & $\begin{array}{l}0.457 \\
(5.11)^{* * *}\end{array}$ & $\begin{array}{l}0.474 \\
(4.69)^{* * *}\end{array}$ & $\begin{array}{l}0.465 \\
(5.25)^{* * *}\end{array}$ & $\begin{array}{l}0.438 \\
(5.33)^{* * *}\end{array}$ & $\begin{array}{l}0.484 \\
(4.70)^{* * *}\end{array}$ & $\begin{array}{l}0.459 \\
(5.19)^{* * *}\end{array}$ \\
\hline Crnta & $\begin{array}{l}0.962 \\
(2.24)^{* *}\end{array}$ & $\begin{array}{l}0.135 \\
(0.29)\end{array}$ & $\begin{array}{l}0.966 \\
(2.25)^{* *}\end{array}$ & $\begin{array}{l}1.130 \\
(2.75)^{* * *}\end{array}$ & $\begin{array}{l}1.010 \\
(2.11)^{* *}\end{array}$ & $\begin{array}{l}0.947 \\
(2.20)^{* *}\end{array}$ \\
\hline Crestcr & $\begin{array}{l}0.947 \\
(1.44)\end{array}$ & $\begin{array}{l}1.243 \\
(1.80)^{*}\end{array}$ & $\begin{array}{l}0.196 \\
(0.22)\end{array}$ & $\begin{array}{l}1.269 \\
(1.35)\end{array}$ & $\begin{array}{l}0.937 \\
(1.11)\end{array}$ & $\begin{array}{l}0.922 \\
(1.39)\end{array}$ \\
\hline Credtcr & $\begin{array}{l}0.904 \\
(2.42)^{* *}\end{array}$ & $\begin{array}{l}0.825 \\
(2.40)^{* *}\end{array}$ & $\begin{array}{l}1.257 \\
(1.90)^{*}\end{array}$ & $\begin{array}{l}1.204 \\
(2.30)^{* *}\end{array}$ & $\begin{array}{l}0.724 \\
(1.10)\end{array}$ & $\begin{array}{l}0.936 \\
(2.51)^{* *}\end{array}$ \\
\hline Credta & $\begin{array}{l}-1.737 \\
(2.04)^{* *}\end{array}$ & $\begin{array}{l}-1.968 \\
(2.62)^{* *}\end{array}$ & $\begin{array}{l}-2.773 \\
(1.86)^{*}\end{array}$ & $\begin{array}{l}-2.197 \\
(1.66)\end{array}$ & $\begin{array}{l}-1.172 \\
(1.01)\end{array}$ & $\begin{array}{l}-1.726 \\
(2.08)^{* *}\end{array}$ \\
\hline Tcrdep & & $\begin{array}{l}0.030 \\
(4.53)^{* * *}\end{array}$ & & & & \\
\hline Depta & & $\begin{array}{l}0.794 \\
(1.94)^{*}\end{array}$ & & & & \\
\hline Proecred & & & $\begin{array}{l}-0.001 \\
(0.15)\end{array}$ & & & \\
\hline Proccred & & & $\begin{array}{l}-0.002 \\
(1.85)^{*}\end{array}$ & & & \\
\hline Proetcr & & & $\begin{array}{l}1.212 \\
(0.70)\end{array}$ & & & \\
\hline Proeta & & & $\begin{array}{l}0.560 \\
(0.30)\end{array}$ & & & \\
\hline
\end{tabular}




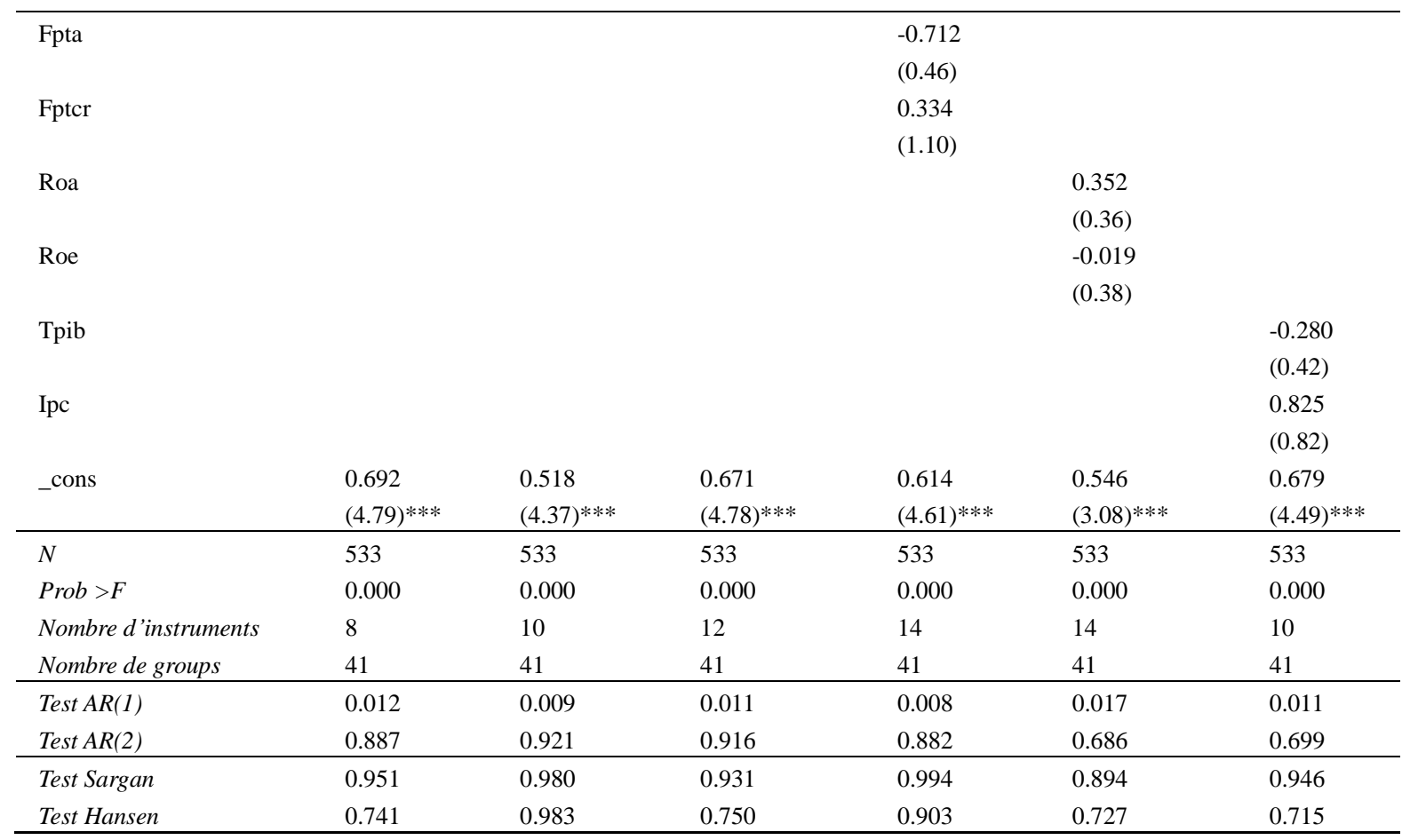

Note. The values in parentheses represent the Student $\mathrm{t}$ statistics calculated and $* p<0.1 ; * * p<0.05$; *** $p<0.01$

Source: author based on calculations under Stata / SE 12.0.

Appendix 2. Summary of the results of the estimates of the nested equations

\begin{tabular}{|c|c|c|c|c|c|}
\hline & Zscore(1) & Zscore(7) & Zscore(8) & Zscore(9) & Zscore (10) \\
\hline L.zscore & $\begin{array}{l}0.457 \\
(5.11)^{* * *}\end{array}$ & $\begin{array}{l}0.477 \\
(4.65)^{* * *}\end{array}$ & $\begin{array}{l}0.519 \\
(2.64)^{* *}\end{array}$ & $\begin{array}{l}0.551 \\
(2.58)^{* *}\end{array}$ & $\begin{array}{l}0.543 \\
(2.49)^{* *}\end{array}$ \\
\hline Crnta & $\begin{array}{l}0.962 \\
(2.24)^{* *}\end{array}$ & $\begin{array}{l}0.123 \\
(0.24)\end{array}$ & $\begin{array}{l}0.115 \\
(0.13)\end{array}$ & $\begin{array}{l}0.137 \\
(0.08)\end{array}$ & $\begin{array}{l}-0.060 \\
(0.04)\end{array}$ \\
\hline Crestcr & $\begin{array}{l}0.947 \\
(1.44)\end{array}$ & $\begin{array}{l}0.969 \\
(0.79)\end{array}$ & $\begin{array}{l}1.053 \\
(0.70)\end{array}$ & $\begin{array}{l}0.968 \\
(0.67)\end{array}$ & $\begin{array}{l}0.955 \\
(0.65)\end{array}$ \\
\hline Credtcr & $\begin{array}{l}0.904 \\
(2.42)^{* *}\end{array}$ & $\begin{array}{l}0.876 \\
(1.20)\end{array}$ & $\begin{array}{l}1.114 \\
(1.37)\end{array}$ & $\begin{array}{l}1.700 \\
(1.58)\end{array}$ & $\begin{array}{l}1.569 \\
(1.55)\end{array}$ \\
\hline Credta & $\begin{array}{l}-1.737 \\
(2.04)^{* *}\end{array}$ & $\begin{array}{l}-2.234 \\
(1.38)\end{array}$ & $\begin{array}{l}-2.545 \\
(1.42)\end{array}$ & $\begin{array}{l}-3.367 \\
(1.54)\end{array}$ & $\begin{array}{l}-3.090 \\
(1.48)\end{array}$ \\
\hline Tcrdep & & $\begin{array}{l}0.029 \\
(4.58)^{* * *}\end{array}$ & $\begin{array}{l}0.031 \\
(4.46)^{* * * *}\end{array}$ & $\begin{array}{l}0.033 \\
(3.10)^{* * *}\end{array}$ & $\begin{array}{l}0.033 \\
(3.20)^{* * *}\end{array}$ \\
\hline Depta & & $\begin{array}{l}0.808 \\
(1.99)^{*}\end{array}$ & $\begin{array}{l}0.672 \\
(1.07)\end{array}$ & $\begin{array}{l}0.828 \\
(0.64)\end{array}$ & $\begin{array}{l}1.018 \\
(0.86)\end{array}$ \\
\hline Proecred & & $\begin{array}{l}-0.006 \\
(1.45)\end{array}$ & $\begin{array}{l}-0.005 \\
(1.08)\end{array}$ & $\begin{array}{l}0.000 \\
(0.03)\end{array}$ & $\begin{array}{l}-0.001 \\
(0.11)\end{array}$ \\
\hline Proccred & & $\begin{array}{l}-0.004 \\
(3.14)^{* * *}\end{array}$ & $\begin{array}{l}-0.004 \\
(2.44)^{* *}\end{array}$ & $\begin{array}{l}-0.002 \\
(0.29)\end{array}$ & $\begin{array}{l}-0.001 \\
(0.12)\end{array}$ \\
\hline Proetcr & & $\begin{array}{l}0.511 \\
(0.40)\end{array}$ & $\begin{array}{l}0.295 \\
(0.13)\end{array}$ & $\begin{array}{l}0.177 \\
(0.08)\end{array}$ & $\begin{array}{l}0.539 \\
(0.22)\end{array}$ \\
\hline Proeta & & $\begin{array}{l}0.071 \\
(0.04)\end{array}$ & $\begin{array}{l}0.657 \\
(0.26)\end{array}$ & $\begin{array}{l}0.333 \\
(0.10)\end{array}$ & $\begin{array}{l}-0.577 \\
(0.20)\end{array}$ \\
\hline Fpta & & & $\begin{array}{l}-0.543 \\
(0.25)\end{array}$ & $\begin{array}{l}-1.664 \\
(0.54)\end{array}$ & $\begin{array}{l}-1.166 \\
(0.42)\end{array}$ \\
\hline Fptcr & & & $\begin{array}{l}0.037 \\
(0.07)\end{array}$ & $\begin{array}{l}0.549 \\
(0.50)\end{array}$ & $\begin{array}{l}0.419 \\
(0.40)\end{array}$ \\
\hline Roa & & & & $\begin{array}{l}-0.665 \\
(0.59)\end{array}$ & $\begin{array}{l}-0.636 \\
(0.59)\end{array}$ \\
\hline
\end{tabular}




\begin{tabular}{|c|c|c|c|c|c|}
\hline Roe & & & & $\begin{array}{l}-0.025 \\
(0.36)\end{array}$ & $\begin{array}{l}-0.036 \\
(0.52)\end{array}$ \\
\hline Tpib & & & & & $\begin{array}{l}-0.293 \\
(0.33)\end{array}$ \\
\hline Ipc & & & & & $\begin{array}{l}1.226 \\
(0.90)\end{array}$ \\
\hline _cons & $\begin{array}{l}0.692 \\
(4.79)^{* * *}\end{array}$ & $\begin{array}{l}0.517 \\
(4.31)^{* * *}\end{array}$ & $\begin{array}{l}0.488 \\
(3.47)^{* * *}\end{array}$ & $\begin{array}{l}0.505 \\
(2.91)^{* * *}\end{array}$ & $\begin{array}{l}0.472 \\
(3.03)^{* * *}\end{array}$ \\
\hline$N$ & 533 & 533 & 533 & 533 & 533 \\
\hline Prob $>F$ & 0.000 & 0.000 & 0.000 & 0.000 & 0.000 \\
\hline Nombre d'instruments & 8 & 14 & 20 & 26 & 28 \\
\hline Nombre de groups & 41 & 41 & 41 & 41 & 41 \\
\hline Test AR(1) & 0.012 & 0.009 & 0.006 & 0.010 & 0.012 \\
\hline Test AR(2) & 0.887 & 0.851 & 0.907 & 0.955 & 0.871 \\
\hline Test Sargan & 0.951 & 0.965 & 0.997 & 0.997 & 0.995 \\
\hline Test Hansen & 0.741 & 0.970 & 0.894 & 0.910 & 0.886 \\
\hline
\end{tabular}

Note. The values in parentheses represent the Student $\mathrm{t}$ statistics calculated and $* p<0.1 ; * * p<0.05 ; * * * p<0.01$

Source: author based on calculations under Stata / SE 12.0.

\section{Copyrights}

Copyright for this article is retained by the author(s), with first publication rights granted to the journal.

This is an open-access article distributed under the terms and conditions of the Creative Commons Attribution license (http://creativecommons.org/licenses/by/4.0/). 